NBER WORKING PAPER SERIES

DOES “SKIN IN THE GAME” REDUCE RISK TAKING? LEVERAGE, LIABILITY AND THE LONG-RUN CONSEQUENCES OF NEW DEAL BANKING REFORMS

\author{
Kris James Mitchener \\ Gary Richardson \\ Working Paper 18895 \\ http://www.nber.org/papers/w18895
NATIONAL BUREAU OF ECONOMIC RESEARCH
1050 Massachusetts Avenue
Cambridge, MA 02138
March 2013

The views expressed herein are those of the authors and do not necessarily reflect the views of the National Bureau of Economic Research.

At least one co-author has disclosed a financial relationship of potential relevance for this research. Further information is available online at http://www.nber.org/papers/w18895.ack

NBER working papers are circulated for discussion and comment purposes. They have not been peerreviewed or been subject to the review by the NBER Board of Directors that accompanies official NBER publications.

(C) 2013 by Kris James Mitchener and Gary Richardson. All rights reserved. Short sections of text, not to exceed two paragraphs, may be quoted without explicit permission provided that full credit, including (๑) notice, is given to the source. 
Does "Skin in the Game" Reduce Risk Taking? Leverage, Liability and the Long-Run Consequences of New Deal Banking Reforms

Kris James Mitchener and Gary Richardson

NBER Working Paper No. 18895

March 2013

JEL No. E44,G28,G33,N22

\begin{abstract}
This essay examines how the Banking Acts of the 1933 and 1935 and related New Deal legislation influenced risk taking in the financial sector of the U.S. economy. The analysis focuses on contingent liability of bank owners for losses incurred by their firms and how the elimination of this liability influenced leverage and lending by commercial banks. Using a new panel data set, we find contingent liability reduced risk taking. In states with contingent liability, banks used less leverage and converted each dollar of capital into fewer loans, and thus could survive larger loan losses (as a fraction of their portfolio) than banks in limited liability states. In states with limited liability, banks took on more leverage and risk, particularly in states that required banks with limited liability to join the Federal Deposit Insurance Corporation. In the long run, the New Deal replaced a regime of contingent liability with deposit insurance, stricter balance sheet regulation, and increased capital requirements, shifting the onus of risk management from bankers to state and federal regulators.
\end{abstract}

Kris James Mitchener

Department of Economics

Leavey School of Business

Santa Clara University

Santa Clara, CA 95053

and NBER

kmitchener@scu.edu

Gary Richardson

Department of Economics

University of California, Irvine

3155 Social Sciences Plaza

Irvine, CA 92697-5100

and NBER

garyr@uci.edu 


\section{Does "Skin in the Game" Reduce Risk Taking? Leverage, Liability, and the Long-run Consequences of the New Deal Banking Legislation}

\section{Introduction}

A defining characteristic of the recent financial crisis was the rise in leverage of financial institutions, a feature that fueled the size of the eventual calamity. Since the crisis, policy makers, pundits, and scholars have asked whether requiring financiers to risk more of their own funds along with their firms, i.e. "keeping more skin in the game," would limit risk taking by financial institutions. We address this question by examining commercial banking from 1910 through 1955, and by focusing our attention on key regulatory changes related to risk taking that arose as part of the New Deal of the 1930s. Prior to the Banking Acts of 1933 and 1935, most commercial bankers were personally liable for losses in the event that their bank failed. This contingent liability applied to the directors, chief executive officers, chief financial officers, and stockholders of all national and most state chartered banks. During the New Deal, legislative reforms eliminated contingent liability for most national and state banks.

The New Deal banking reforms had long-lasting consequences that may have contributed to the leveraging and risk taking that fueled the credit boom of the 2000s. We focus on how New Deal banking legislation from the mid-1930s altered incentives for financial firms to manage their risk, shifted oversight of commercial banks to new federal agencies, and left the oversight of risk in investment banks to themselves or to regulatory agencies with little existing experience or authority to manage it.

Our estimation strategy exploits variation in liability laws across states and variation in changes in these laws over time to identify the influence of contingent liability on risk taking by banks. Using a new panel data set, we find contingent liability reduced risk taking. In states with contingent liability, banks used less leverage and converted each dollar of capital into fewer loans, and thus could sustain larger loan losses (as a fraction of their portfolio) than banks in limited liability states. In states with limited liability, banks had more leverage and risk, particularly in states that required banks with limited liability to join the Federal Deposit Insurance Corporation. The New Deal replaced a regime of contingent liability with stricter balance sheet regulation and 
increased capital requirements, shifting the onus of risk management from banks to state and federal regulators.

Our analysis begins with an examination of the different liability regimes that applied to commercial banks, the reforms of the New Deal, and theoretical reasons why liability laws influenced risk-taking by banks. Section III describes the new data set that we use to estimate the effects of contingent liability, including detailed information on the liability laws commercial bankers faced in each state. We track changes in regulatory regimes at the state and national level from 1910 through 1955. We combine this regulatory information with state-level aggregates on the balance sheets of banks. Section IV uses the panel data to analyze the effects of bank liability laws and finds that, when contingent liability existed, it deterred risk taking. Section V concludes by discussing the long-run consequences of the financial reforms of the 1930s for the U.S. financial system.

\section{Contingent Liability}

\section{A. Background}

In an effort to reform the present structure of financial regulation, policymakers have looked back at the pivotal legislation of the 1930s for guidance. Some commentators have argued that the Banking Acts of 1933 and 1935 set the U.S. financial system on a trajectory of safety and stability that promoted long-run growth in the economy; it is argued that the virtues of Depression-era regulation were stripped away when banking reform began in the 1990s. ${ }^{1}$ Others have cast the 1930s legislation as a misdiagnosis of the underlying problems of the 1930s (Kroszner, 1998), and a continuance of practices (i.e., unit banking, and the Real Bills Doctrine) or extension of them (deposit insurance) that undermine financial stability (Barth, Caprio, and Levine 2006; Demirguc-Kunt, Kane, and Laeven 2009; Calomiris 2008a, 2011). In this paper, we revisit the Banking Acts of 1933 and 1935 to shine new light on changes that affected the incentives and risk taking of financial firms.

By the 1830 s, most states had passed laws limiting the liability of non-banking corporations (Oesterle, 1992). Until the 1930s, however, limited liability was the

\footnotetext{
${ }^{1}$ See, for example, Kuttner (2007) and Stiglitz (2009).
} 
exception rather than the rule. Between the Civil War and the Great Depression, most states had laws that made stock holders responsible for a portion of the bank's debts when banks failed. Contingent liability gained a further foothold when the National Banking Act made double liability a requirement for national banks:

"The shareholders of every national banking association shall be held individually responsible, equally and ratably, and not for one another, for all contracts, debts, and engagements of such association to the extent of the amount of their stock therein, at the par value of, in addition to the amount invested in such shares..." (U.S. Revised Statutes sec. 5151 (1875) 12 U.S.C., sec.63)

Double liability meant that if banks failed, stockholders would lose the amount invested in the stock (due to the failure) and, if assets were insufficient to payoff creditors and depositors, stockholders were held responsible for an additional sum not exceeding the par value of their stock. During the nineteenth and early twentieth centuries, the system of double liability was vigorously enforced; more than 50 U.S. Supreme Court rulings and hundreds more in state and local courts affirmed its validity. The federal enforcement of double liability recovered $\$ 68.4$ million dollars between 1865 and 1934, a significant fraction $(28.3 \%)$ of total losses to all creditors of failed national banks during that period (Macey and Miller, 1992, p.57).

A large portion of these recoveries came out of the pockets of key decision makers at commercial banks. A bank's top corporate officer, then referred to as president and cashier, and now known as chief executive officer and chief financial officer, sat on the board of directors. Federal law required all members of the board of directors to own a minimum of $\$ 1,000$ dollars in stock (at par value), and most state laws had similar provisions. Laws in some states required directors to hold larger stakes. In Iowa, for example, each director of a state bank with capital above $\$ 50,000$ had to hold $5 \%$ of the outstanding shares (Garlock, 1926). Because stocks tended to be concentrated in small numbers of individuals, many directors and officers ended up owning more stock than the minimum (Manfrini, 1959). ${ }^{2}$ This concentrated pattern of stock holding aligned the

\footnotetext{
${ }^{2}$ This pattern resembled the pattern for small corporations in the United States from the 1930s through the 1950s (Perlo 1952). By the 1930s, dispersed stock ownership shifted control of the largest firms in the
} 
incentives of owners and managers, creating considerable overlap between these two groups. When coupled with double-liability legislation, it ensured the decision-makers kept substantial "skin in the game."

The number of states with double liability continued to expand in the first decades of the $20^{\text {th }}$ century. In 1910,31 states imposed double liability on bank stockholders. Colorado (triple liability) and California (unlimited liability) imposed even higher limits (Vincens, 1957). Apparently, in reaction to the panic of 1907, several states moved to double liability. Nevada and New Hampshire did so in 1911. Arizona, Arkansas, and Oregon changed in 1912, and Mississippi imposed it in 1914 (White, 2013). By contrast, the Idaho Supreme Court ruled double liability unconstitutional in that state in 1923. In 1929 , on the eve of the Great Depression, double liability (or greater) existed in 38 states. Table 1 outlines these patterns. The column "Status 1910" indicates the liability that a state imposed on the banks that it chartered. The column "begin" indicates the year that a state with limited liability in 1910 imposed double liability on the outstanding capital stock of all banks chartered in the state and all subsequent issues of bank capital. In states that do not appear in the table, limited liability prevailed in 1910 and thereafter.

\section{B. How does Contingent Liability Influence Risk Taking?}

According to most scholars, contingent liability emerged as a way to protect depositors from "risk shifting." Depositors are at an informational disadvantaged relative to shareholders, who know more about the particular assets held by banks. Contingent liability puts more equity at stake for stockholders and has the effect of making them stay on the linear portion of their payoff matrix over a greater range of outcomes (Esty, 1998). By reining in moral hazard, contingent liability potentially reduces the incidence of bank failures and the size of losses incurred by depositors and unsecured creditors. Moreover, since creditors know that banks will act with less risk, they may in turn offer banks lower cost funds (Kane and Wilson, 1996, Esty, 1998).

Empirical evidence suggests that during the national banking era double liability reined in risk taking. For example, Macey and Miller (1992) show that from 1913-1928,

United States from owners (i.e. stockholders) to managers. For the largest member banks, that shift occurred during the 1950s (Vernon 1970, US Congress 1963a, 1963b, 1966). 
voluntary liquidations for national banks outpaced involuntary liquidations by a ratio of nearly three to one. Macey and Miller (1992) also show that recovery rates from failed banks with double-liability exceeded recovery rates from failed banks with limited liability. Using aggregate data from four U.S. states, Esty (1998) shows that the number of new banks declines monotonically with increased liability during the period 19001919. These studies, of course, examine indirect proxies for leverage and risk-taking. Our essay is the first that directly analyses these issues.

\section{Legislative Changes in the 1930s}

If double liability appeared to protect depositors and creditors and limited risk taking by banks, why did it then disappear? Vincens (1957) suggests that, with the Depression and waves of failures, the costs became too great. Once bank failures began en masse, depositors had little recourse for securing claims against shareholders as many of them were already in serious financial difficulty. As a result, assessments placed on national bank shareholders never amounted to more than 49.8 percent. Moreover, during the 1920s, bank stock ownership broadened considerably. Many of these new stockholders purchased shares of bank stock during the equities boom of the 1920s. Others inherited shares from parents and grandparents who had been associated with the bank in the past. This gradually growing class of shareholders lacked an insider connection to the failing bank and had little or no ability to monitor the bank's behavior, yet they faced assessment; and unlike bank executives, these shareholders may not have fully considered the implications of stock ownership of banks with contingent liability (Macey and Miller, 1992). It was also believed that the threat of contingent liability being enforced when banks became insolvent was thought to be depressing bank share prices in the 1930s, thus weakening banks' desire to maintain the system in the face of significant macroeconomic distress (Vincens, 1957). At the trough of the depression, policymakers and bankers frequently emphasized the need to recapitalize the financial system. Double liability may have impeded this goal as it deterred investors from purchasing stocks in new or struggling banks. It may have also prevented the Reconstruction Finance Corporation from purchasing preferred stocks in banks. 
Kane and Wilson (1996) suggest that regulatory and/or economic shocks can lower the value of unlimited liability. They suggest that the private interest theory of regulation helps account for the demise of double liability in the 1930s, arguing that the benefits that had once accrued to stockholders of large national banks and large statechartered banks in double liability states evaporated in the early 1930s. Since all banks potentially benefited from decreased expenses associated with monitoring, the passage of federal deposit insurance reduced depositors' future claims and left little support from banks for maintaining contingent liability.

As bank failures mounted in the 1930s and the financial system wound its way toward collapse in 1933, public opinion began to turn against double liability as a way of protecting depositors and minimizing failures. Limiting risk taking of owners through contingent liability provided little cover for depositors facing a large and prolonged macroeconomic shock because it did not ensure that depositors would be compensated (even partially) at a time in the future when shareholders might be able to pay. In 1933, Congress amended the Federal Reserve Act and National Banking Act and removed double liability from shares issued after June $16^{\text {th }}, 1933$. This provision went into effect after July 1, 1937, and required national banks to give six-months notice of its intention to end double liability (49 STAT. 708 (1935), 12 U. S. C., sec. 64a). Then, in 1935, Congress further amended the National Bank Act and the Federal Reserve Act, permitting (but not requiring) national banks to eliminate double liability on all shares.

Having weakened depositor protections, legislators sought new alternatives to replace contingent liability. Foremost among the new policies to protect depositors was the creation of federal deposit insurance, initially enacted in 1933. The 1933 and 1935 acts also moved to strengthen capital requirements to ensure that banks had "skin in the game." Hearings on the Banking Act of 1935 highlight the reorientation of risk management toward the use of regulatory capital standards and surplus. Anticipating that legislators were moving in this direction, the Comptroller of Currency noted in his 1934 Annual Report that "in the event that it is determined to completely eliminate this assessment of liability on shareholders, it is suggested that serious consideration be given to providing for increasing the surplus of national banking associations until same equals the amount of common stock, thereby restoring to the bank's creditors the protection now 
given by the potential assessment liability of the shareholders and maintaining a sound banking structure." In testimony on the Banking Act of 1935, the Comptroller again advocated that surplus should equal 100 percent of capital. ${ }^{3}$ As a result, Congress modified the national banking act, doubling the minimum capital of $\$ 25,000$ for new banking corporations (48 STAT. 185, 12 U.S. C. A. 51 (1933) and mandating that every national bank retain 10 per cent of its net earnings until the surplus equaled the total outstanding common capital stock (49 STAT. 712 (1935), 12 U. S. C., sec. 60).

With the termination of double liability for national and Fed member banks, pressure mounted for states to eliminate contingent liability for state-chartered banks. In order to avoid losing chartered banks, many states responded quickly and passed limited liability laws; others lagged, often because of the need to amend state constitutions. The last three columns of Table 1 show how states changed bank liability laws. 35 states removed double-liability from new and existing bank stock. 30 states changed liability on new and existing bank stock with the changes taking effect within the same calendar year. Five states reduced liability on the issuance of new bank stocks a year or more before reducing liability on existing bank stock. One state, Vermont, authorized limited liability for bank stocks issued after March 24, 1935, but retained double liability on all bank stock issued before that date.

States altering double-liability laws often simultaneously changed other rules that affected bank risk taking. At least 15 states eliminated double liability only for banks that joined the Federal Deposit Insurance Corporation (FDIC). At least 12 states eliminated double liability only for banks that met increased requirements for retained surplus. At least 16 required banks seeking to eliminate double liability to notify depositors in advance, either in person, through the mail, or by advertising in newspapers. ${ }^{4}$ Double liability then lapsed after a waiting period ranging from one to six months. The latter was the most common, and was the waiting period required of national banks and of banks in the state of New York. Articles published in major newspapers on 2 July 1937 noted that most prominent national banks published notices of intent to terminate double liability as

\footnotetext{
${ }^{3}$ United States Congress. House of Representatives. Hearings before Committee on Banking and Currency on H. R. 5357 (Banking Act of 1935),74th Cong., 1st Sess., pp. 147-8

${ }^{4}$ The preceding sentences begin with the phrase "at least" because, at present, we lack a complete accounting of all changes in state banking rules and practice that accompanied changes in double-liability.
} 
soon as possible and terminated double liability on the first day possible. In the dozen states that coincided with national timing, the principal state-chartered banks followed suits. ${ }^{5}$

Though it sounded the death knell for contingent liability, the Banking Acts of 1933 and 1935 and their state counterparts did not formally abolish it. Pursuant to the creation of the FDIC and subsequent legislative revisions, depositors waived their rights to contingent liability upon receiving payment via deposit insurance (52 STAT. 442 (1938), 12 U. S. C., sec. 264 (1)(7); repealed and reenacted by 64 STAT. 873 (1950), 12 U. S. C., sec. 1821(g)). It took until 1953 for contingent liability to be abolished formally. ${ }^{6}$

\section{Data}

To understand the impact of removing contingent liability from the banking system, we create a panel data set of legal changes and aggregate balance sheet data at the state level for the U.S. banking system from 1910 through 1955.

Our panel concerning double liability legislation extends the work of previous scholars, particularly Marquis and Smith (1937), Vincens (1957), Macey and Miller (1992), and Grossman (2007). ${ }^{7}$ We collect information from those scholars and additional sources including: the NBER/University of Maryland State Constitutions Database;

\footnotetext{
${ }^{5}$ See, for example, Wesley Smith, “The March of Finance," Los Angeles Times, July 2, 1937, p. A17.

6 "In the case of each association which has not caused notice of termination of liability to be published prior to May 18, 1953, the Comptroller of the Currency shall cause such notice to be published in the manner provided in this section, and on the date six months subsequent to such publication by the Comptroller of the Currency such additional liability shall cease." (67 STAT. 27 (1953), 12 U. S. C., sec. 64a.)

${ }^{7}$ Grossman (2007) provides data on states with double liability in 1870, 1900, and 1930. Macey and Miller (1992) provide information on (i) states that possessed double liability in the years 1912 and 1931 and (ii) states that abolished double liability by 1944. Marquis and Smith (1937) describe the evolution of state legislation before 1930, the status of all states laws in 1930, and the legislative changes that occurred in most states (including requirements for opting out of double liability) through the end of 1936. Vincens (1957) provides a table indicating the "available methods of terminating liability" for states that had not abolished it as of 1956 (Vincens 1957 pp.277-8). For most states, Vincens' table provides the constitutional provision or legal code pertaining to double liability and information about the requirements for opting out of double liability, such as joining the Federal Deposit Insurance Corporation or giving public notice of termination of liability. The listed requirements, however, is not exhaustive, and the table does not indicate the initial date on which the state allowed (or forced) banks to abandon double liability. Instead, the table cites the date of the statute currently in force. Arkansas, for example, eliminated double liability for new bank stock in 1933 and for bank stock already outstanding in 1935.
} 
Bankers Magazine ("In the Months News," a column that we checked for each month from 1933 through 1940); the Banking Law Journal ("Banking Legislative Trends in the States" and "Banking Decisions," two columns which we checked in every issue from 1933 through 1955); the Wall Street Journal (in particular, articles on 15 May 1936, 9 March 1937, 30 June 1939); the New York Times (particularly articles 16 August 1936, 27 May 1938); and Paton's Digest of Legal Opinions (1926 Edition and 1946 Supplement).

These sources enable us to date adoptions and departures from double-liability regimes. Dating adoptions tends to be easy and clear. In almost all cases, states adopted contingent liability for the stock of all banks chartered in their state at an instant in time rather than phasing in double liability slowly over time. The additional liability came into effect soon after passage of the act or at beginning of next calendar year.

Dating departures from contingent liability is a bit less straightforward, and potentially complicates our analysis. First, the Federal government and some state governments initially eliminated double liability for newly issued bank stock and later for all bank stock. Vermont eliminated double liability only for newly issued bank stock, and as of 1955, had not eliminated liability for outstanding stock. Second, in most cases, provisions associated with its elimination usually came into effect between one month and one year after the legal change. Third, participation in the program was optional. Banks could choose to opt out of double liability. Doing so required them to provide public notice, ranging from one month to six months prior to the cessation of liability. A non-member, non-FDIC state bank's decision to change its liability status was almost always voluntary; it was ubiquitous, but not universal. Most state and national banks gave notice immediately. This was noted in articles in major newspapers near the date that double liability ceased for outstanding shares of national and many state chartered banks. ${ }^{8}$ Almost all banks opted out of double liability eventually. In 1953, "all but 25 out of almost 5,000 national banks had published the required notice and opted out of double liability (Macey and Miller, 1992, pp. 38-9)." By 1957, all but 96 state-chartered banks had given notice and opted out of double liability (Vincens, 1957, p. 277).

\footnotetext{
${ }^{8}$ For example, see Los Angeles Times, July 2, 1937.
} 
Because of these complications, we date define a state's departure from double liability in as the first year in which all of the state-chartered banks in state had opportunity to opt out of double liability for all existing stock prior to July 15 of that year. In states without the opt out provision, we date the end of double liability to the year in which laws eliminated double liability for banks before July 15. July is the cutoff because our balance sheet information comes from the banks' spring call report, typically collected on the last business day in June.

Balance sheet data are from All Bank Statistics, United States, 1896 to 1955. All Bank Statistics reports data from bank balance sheets aggregated by state and year. The data originated with balance sheets indicating the state of financial institutions at their spring call, which usually came near the end of June, and which the federal (and most state governments) fixed in the early twentieth century as the last business day in the month of June. The data represent aggregates of the balance sheets of all banks in a state. When we report figures on total equity, therefore, we are reporting the total equity of all banks in a state. When we analyze the asset-equity ratio (often referred to as leverage or balance-sheet leverage), we are analyzing the average asset-equity ratio of all banks in a state, which is calculated by summing the assets of all banks in a state and dividing that sum by the sum of the equity of all banks in a state. ${ }^{10}$

\section{Contingent Liability and Risk Taking}

\footnotetext{
${ }^{9}$ This publication represents a retrospective study conducted by the Federal Reserve Board of Governors, the Federal Deposit Insurance Corporation, and the Office of the Comptroller of the Currency during the 1950s. It employed data from materials previously published by state and federal regulators, from state and federal archives, and from privately printed bankers' directories. The archival and private sources enabled investigators to fill gaps in existing series. Some of these gaps were substantial. The State of New York, for example, did not collect call reports from state chartered banks during the years 1933 and 1934. All Bank Statistics' data concerning these institutions in those years is interpolated. We analyze only those series that were accurately and consistently measured throughout our study period. We examine data collected from FRASER's online database and data digitized by Mark Flood, which are available via the Inter-university Consortium for Political and Social Research (Flood 1998).

${ }^{10}$ Note that to compute values for state-chartered banks, we subtract values for national banks from values for all banks using Flood (1998). For seventeen states, this procedure lumps together data on state-chartered commercial banks, state-chartered mutual savings banks, state-chartered trust companies, and private (unchartered) banks. Mutual savings banks played a minor role in the financial systems for nine of the seventeen states where data cannot be separated. For eight states (CT, ME, MD, MA, NJ, NY, RI, VT), mutual savings banks feature more prominently. To ensure that differences at the state level in the reported financial institutions does not influence our statistical results, we replicate all calculations, figures, and tables excluding those eight states excluding these states. Excluding those states does not alter our main findings.
} 


\section{A. Time Series Evidence from Bank Balance Sheets}

Our empirical strategy focuses on the microeconomic consequences of contingent liability laws by examining bank balance sheet characteristics as outcome variables. We compare the experience of state-chartered banks operating in states with and without double liability to the experience of national banks operating in those same states. We exploit the variation in double-liability laws across states, within states over time, and between states and the national banking system. This variation enables us to identify the effects of contingent liability on bank risking and to separate contingent liability's influence from confounding variables, state-specific factors, and changes in the economic and financial system.

Figure 1 displays the number of states subject to double liability on owners' equity, the total number of banks in the United States, and the total number of banks subject to double liability. A small number of states adopted double liability at the beginning of our panel. Most states eliminated double liability in the late 1930s. The number of banks under contingent liability peaked about a decade after the last state adopts double liability. The initial peak in the number of banks under double liability, and the initial decline in the number of banks under double liability, reflected trends in the total number of banks in the United States. Both fell rapidly during the 1920s and 1930s. During this period, the proportion of banks under double liability remained roughly constant. After 1935, the fraction declined rapidly, as states switch their double liability regimes.

Figure 2 plots average leverage for state and nationally-chartered banks from 1910-1955. ${ }^{11}$ Following standard financial accounting, we define the ratio as the bank's assets divided owners' equity, which is the sum of the book value of paid up capital, surplus, undivided profits, unpaid dividends, and all other retained earnings on the balance sheet (other than reserves for losses and liabilities for future expenditures, such

\footnotetext{
${ }^{11}$ To be precise, we calculate the state level averages, and then plot the average across all states. We focus on this average of averages because it illustrates the variation which our statistical methods exploit: the variation in averages across states. Directly calculating the national average or calculating an average of state averages weighted by the assets of banks in each state yield similar time series variation to what is shown in Figure 2.
} 
as taxes). ${ }^{12}$ This definition permits us to compute leverage directly from bank balance sheets; since regulators collected these data, they are readily available for our sample period. ${ }^{13}$ The ratio thus indicates how many dollars a bank invests (in financial and physical assets) for each dollar that its owners invested in the firm.

Figure 2 shows that at the beginning of the century, leverage ratios hovered between 5 and 6. After the creation of the Federal Reserve and during World War I, they rose to between 7 and 8. Prior to these events, state-bank leverage on average exceeded national-bank leverage. By the 1920s, national bank leverage exceeded state bank leverage, possibly because the Federal Reserve reduced liquidity risks for member banks. All national banks belonged to the Federal Reserve System while only a fraction of statechartered banks joined the system. Leverage falls during the contraction of the early 1930s, but with the dissolution of double liability during the New Deal, it begins to rise. During World War II, leverage peaks at more than 17 for state banks and 20 for national banks. After the war, leverage falls gradually. The ratio then stabilizes at double the value prior to the start of the Great Depression.

Figure 3 displays the ratio of equity to total loans. This ratio reveals the percentage decline in the value of a bank's loan portfolio that would exhaust its capital, force it into insolvency, and (in double liability states) trigger assessments on stockholders. It is meant to capture the default risk of a bank's loan portfolio. Banks in the early twentieth century possessed large equity buffers. The figure suggests that, in 1910, the average state bank would have remained solvent even if its loans lost one-third of its value or if one-third of their borrowers stopped repaying their loans. After the creation of the Federal Reserve, banks assumed greater lending risk and employed capital more intensively. After the collapse of the banking system in the 1930s, surviving banks became extremely conservative. In some years, the average bank could sustain losses of more than 40 percent of its loans and remain solvent.

\footnotetext{
${ }^{12}$ For a review of the concept of leverage, see Katia D'Hulster, "The Leverage Ratio: A New Binding Limit on Banks," World Bank Note Number 11, December 2009.

${ }^{13}$ It represents the principal form of leverage available to commercial banks during the first half of the twentieth century. While most of the financial concepts, contracts, and organizations (such as mortgage backed securities and bank holding companies) that today enable financial institutions to increase exposure to risk and return also existed during the period that we study (in fact, many of these concepts were invented and popularized in the United States in the early twentieth century), regulations discouraged (and in many cases prohibited) commercial banks from employing these instruments before the 1980s.
} 
Retained earnings as a share of loans provides a measure that can be used to understand the losses on loans that would impair the average bank's capital, absorb all of a bank's retained earnings, and consume the value of its paid-in capital. If magnitude would likely threaten a bank's ability to operate, scare potential creditors, and likely trigger regulatory intervention, including a forced merger with a healthier institution, requiring the bank to raise additional capital, or forced liquidation. In double-liability states, regulators could do this by imposing assessments up to the par value of outstanding stock. Figure 4 displays retained earnings as a share of loans. This ratio fell after the creation of the Federal Reserve in the 1910s and 1920s. It then rose substantially during the 1930s, partly as a reaction to rising risk and partly in response to legal changes requiring banks to increase their surplus (i.e. retain additional income) in order to opt out of double liability. ${ }^{14}$

The cash-to-asset ratio reveals the fraction of bank assets invested in extremely safe and liquid assets. Figure 5 shows the average cash-to-asset ratio, revealing the fraction of bank assets held in safe and liquid assets. ${ }^{15}$ Banks held proportionately more safe assets following the banking crises of the 1930s. Note that banks cash holdings at times varied for reasons beyond their control. ${ }^{16}$

Figure 6 depicts the loan-to-asset ratio. During our sample period, commercial loans lent primarily to local businesses, and to a lesser extent, to individuals or on real estate. This ratio remained relatively steady until the 1930s and then declined rapidly as banks limited lending due to rising default risk. Banks shifted toward bonds, whose liquidity and high real yields in a deflationary environment appeared increasingly attractive (White, 2010; Friedman and Schwartz, 1963).

Figures 7 and 8 illustrate important aspects of the legislative reforms of the 1930s. These reforms, of course, provide the variation that is central to our panel regressions in

\footnotetext{
14 To reiterate, in the 1930s almost all states that changed double liability laws did so by allowing banks to opt out of it or to retain double liability for their shareholders. The same was true for national banks.

${ }^{15}$ Cash includes cash items (such as checks in the process of collection) and deposits at other banks (including reserves deposited in money center banks and Federal Reserve Banks).

${ }^{16}$ All banks faced reserve requirements, which specified fractions of certain types of deposits that had to be held as cash in their vault or deposits at a private or Federal Reserve Bank. These requirements varied across time, states, cities (country, reserve, central reserve), and clearing houses. Policies of the Federal Reserve also influenced reserve balances, particularly the open-market operations and changes in reserve requirements during the 1930 s.
} 
the next section. Figure 7 indicates the assets of banks operating under different regimes for ending contingent liability. Figure 8 indicates the assets of banks required to either (1) join the FDIC or (2) increase surplus if they wished to opt out of double liability. These figures tell a consistent story. In most cases, eliminating double liability was part of a package of reforms that required banks to protect depositors' interests by adding insurance, raising capital, or both.

\section{B. Panel Analysis}

Our empirical analysis examines whether key balance-sheet ratios, such as leverage, differed for banks in states with and without contingent liability. ${ }^{17}$ We begin with an assumption that a state banks' balance sheet reflects market forces, state laws, and state economic conditions. Equation (1) summarizes this relationship.

$$
S_{i t}=\alpha_{S}+\delta L_{i t}+\beta_{S} X_{i t}+\varepsilon_{i t}^{S},
$$

where $i$ denotes state and $t$ indicates the year. $S$ is a state-bank balance sheet characteristic, such leverage. $L$ are the laws of the state affecting state banks, including contingent liability, but in the later regressions, a vector of laws related to contingent liability and the conditions imposed on banks that opted for limited liability. $X$ are economic conditions that influence banks' behavior such as local business conditions, preferences for holding currency relative to deposits, investment returns, and changes in employment.

For the period of interest, consistent measures of state and local economic conditions (the $X$ 's) do not exist. Hence, to control for these factors, we exploit the fact that all national banks faced identical rules and regulations, regardless of their location in the U.S., but individually, were subjected to the same location-specific market and economic conditions that state banks faced. Equation (2) summarizes this relationship.

$$
N_{i t}=\alpha_{N}+\beta_{N} X_{i t}+\varepsilon_{i t}^{N},
$$

\footnotetext{
${ }^{17}$ For ease of exposition, any state without limited liability is defined as a "contingent liability" state.
} 
using $N$ as the same balance sheet characteristic we consider for state banks, but the statespecific value for national banks. Solving equation (2) for $\mathrm{X}$ and substituting the result into (1) yields:

$$
S_{i t}=\left(\alpha_{S}-\alpha_{S} / \beta_{S}\right)+\left(\beta_{S} / \beta_{N}\right) N+\left(\varepsilon_{S}-\varepsilon_{N} / \beta_{N}\right) .
$$

Equation 3 indicates how national bank outcomes can proxy for state-specific economic conditions that also influence state banks located in the same state $i^{18}$ Chung and Richardson (2007) discuss the potential bias caused by the correlation of the state and national bank error terms. In our specifications, such biases are minimal, and the direction of them works against our results.

We thus estimate different specifications of the following equation:

$$
S_{i t}=\alpha+\delta L_{i t}+\beta N_{i t}+\varepsilon_{i t},
$$

where the coefficient $\beta$ indicates how the behavior of state-chartered banks in a state differed from the behavior of nationally-charted banks in state i, (i.e., $\beta=\beta_{\mathrm{S}} / \beta_{\mathrm{N}}$ ). The constant indicates how average state-bank choices differed from average national bank choices, i.e. $\alpha=\alpha_{S}-\alpha_{N} / \beta_{N}$. Note that the constant could be disaggregated into state and year fixed effects by adding subscripts $i$ and $t$. The regression thus examines how the behavior of state banks (the treated group, with respect to state banking laws) deviates from national banks (the control group not affected by state banking laws).

Table 2 examines how leverage is affected by bank liability laws. The dependent variable is the asset-to-equity ratio. Data are aggregated at the state level so that the dependent variable is the weighted average of the asset-equity ratio for all state-chartered banks in a state. Column (1) regresses the state leverage ratio on an indicator variable set equal to unity if the state possessed double liability as well as state and year fixed effects. The fixed effects control for changes in leverage ratios over time and for state specific effects correlated with liability laws of the states. Standard errors are calculated using the

${ }^{18}$ See Mitchener $(2005,2007)$. 
Huber-White method, which generates consistent standard in the presence of heteroskedasticity and autocorrelation. ${ }^{19}$ The coefficient reveals that, on average, leverage ratios in limited liability states exceeded leverage ratios in double liability states. The null hypothesis that leverage in limited liability states exceeded leverage in contingent liability states cannot be rejected at the one-percent level. The effect is also large in economic terms. During the 1920 and early 1930s, the average leverage ratio for all banks in the United States was around seven. The measured coefficient (-0.72) is roughly one-tenth of the average, and approximately equal to 70 percent of the capital of the average bank. In other words, our estimate indicates that the typical state-chartered bank with a capital of $\$ 50,000$ and located in a limited liability state held about $\$ 36,000$ more in investments (assets) than an equivalent state-chartered bank located in a doubleliability state. To control for state-specific factors influencing bank leverage, column (2) adds the asset-equity ratio for national banks. Even after controlling for this influence, leverage ratios continue to be higher in limited liability states and lower in double liability states, about $50 \%(-0.495)$ of the capital of the average bank.

Table 3 examines how the loan losses that a bank could absorb before becoming impaired or insolvent varied across states with different liability regimes. In Column (1), the dependent variable is average retained earnings as a fraction of loans for all state chartered banks in each state. This ratio indicates the losses that a bank could sustain on its loan portfolio before its capital became impaired - an event which typically triggered regulatory intervention. The independent variables include an indicator for double liability, the equivalent ratio for national banks in each state, and state and year fixed effects. The coefficient indicates that banks in states with double liability could sustain larger losses as a fraction of their portfolios before running out of retained earnings. The magnitude of the effect is substantial in economic terms. In the 1920s, retained earnings over loans averaged about 10 percent. The variance around this average was about 1.5 percent. The coefficient of 0.682 indicates that double liability raised this ratio by about seven percent (i.e. from an average of approximately 9.65 to 10.35), and that double liability's impact was large relative to the other factors generating variance in the data.

\footnotetext{
${ }^{19}$ We find similar results when we cluster the standard errors either by year or by year and region.
} 
In Column (2), the dependent variable is the equity-loan ratio, which indicates the fraction of the loan portfolio that the average bank could lose before becoming insolvent. The independent variables include an indicator for double liability, the equivalent ratio for national banks in each state, and state and year fixed effects. The coefficient indicates that banks in states with double liability could sustain larger losses as a fraction of their portfolios before becoming insolvent. The coefficients from both columns indicate that banks in states with double liability converted each dollar of capital into few loans than banks in states with limited liability. ${ }^{20}$ The magnitude of this effect was substantial. In the 1920 s, the equity-loan ratio averaged about 20 percent. The variance was about 2 percent. The coefficient of 1.667 indicates that double liability raised this ratio by about eight percent (i.e. from an average of 19.2 to 20.8) and that double liability generated a large share of the variance in the data.

Table 4 examines leverage in banks after the creation of the Federal Deposit Insurance Corporation (FDIC). We use the same empirical strategy as the preceding tables, but limit the analysis to 1933-1955 in order to focus on the evolution of leverage since the New Deal. We include three additional indicator variables. The first indicates whether a state required banks that opted out of contingent liability to join the FDIC. The second indicates whether a state required banks that opted out of contingent liability to notify depositors before the change, and the third indicates where a state required banks that opted out of contingent liability to increase surplus (i.e. retain additional earnings). Column (1) shows that the leverage ratio of banks in states with contingent liability was about 3 percentage points lower than the leverage of banks in states with limited liability. During the 20 years following the banking holiday in 1933, the leverage of banks in states with contingent liability averaged about nine. The leverage ratio in states where banks could opt out of double liability averaged about 12 .

\footnotetext{
${ }^{20}$ The results shown in Table 3 shed light on differences in the existing empirical literature. Previous scholars present regressions like ours, some possessing positive coefficients and others possessing negative coefficients (e.g. Vincens, 1957 and Esty,1998). Scholars note that their results depend upon their particular sample and specification. The results of contingent liability appear, in many cases, to vary over time (Grossman, 2001, 2007). Given the dramatic changes in the structure and performance of banks over time and across space, it is possible to pick samples (particular years or states) that generate almost any result. We believe that the panel structure of our analysis avoids potential pitfalls, by enabling us to calculate the average impact of contingent liability controlling for variation over time, space, and local economic conditions, and return to an explicit comparison with the existing literature in our robustness checks.
} 
Leverage of banks required to join the FDIC moved in the other direction. The coefficient on the requirement to join the FDIC was 1.7. Controlling for local conditions, state fixed effects, and year fixed effects diminishes all of these coefficients. Column (3) shows that, with a full set of controls and robust standard errors, leverage increased by about 0.5 for banks that were required to join the FDIC. Leverage decreased by 0.5 in states where banks were required to increase equity when opting out of contingent liability. In states that required both membership in the FDIC and increased equity, the effects appear to have cancelled each other out, and average leverage did not change. These results suggest that a substantial share of the increase in leverage after the New Deal occurred because federal and state legislation swapped contingent liability for deposit insurance.

\section{Comparison with Prior Studies}

To put our results in some perspective, we relate them to previous empirical and theoretical studies, in particular, those of Grossman (2007) and Calomiris and Wilson (2004). Grossman (2007) argues that contingent liability reduced risk taking. We agree with that assessment, but our statistical results differ from that earlier paper in two important ways. First, we find the impact of double liability persists during the 1930s. Second, we observe a consistent and substantial relationship between higher contingent

liability and lower leverage ratios, but find no statistically significant relationship between contingent liability and cash holdings (measured either as the cash-to-asset ratio or the cash-to-deposit ratio). Grossman (2007) finds the opposite statistical relationships.

There are several reasons why our statistical results differ from Grossman (2007). Our study differs in terms of coverage across states and over time. In particular, the earlier study excludes several states because the author failed to locate information on contingent liability. Our empirical model also differs from Grossman (2007) in two key respects. Grossman (2007) includes the lagged value of the dependent variable as an independent variable and the estimates use transformed balance sheet ratios, computed as the natural $\log$ of the balance sheet ratio divided by one minus the ratio (i.e., $\ln (x /(1-x))$.

Table 5 indicates that differences between our analysis and the earlier study arise from both of these factors. Columns 1 and 4 of the table apply both of the Grossman 
(2007) modeling assumptions to our data set for two balance-sheet measures: (1) the cash-deposit ratio and (2) the asset-equity ratio. Columns 2 and 5 only include the lagged dependent variable assumption, whereas columns 3 and 6 only include the log transformation assumption. Column (2) demonstrates that for the cash-to-deposit ratio, regressing on the lagged value of the dependent variable generates the difference between our result and the earlier study. Column (3) shows that Grossman's transformation of the cash-to-deposit ratio alone does not generate his finding for the cash-deposit ratio. The results in Column (4) resemble the findings in Grossman (2007) for leverage, applying both assumptions. Column (5) demonstrates that, for leverage, adding the lagged value of the dependent variable does not generate this result. Column (6) suggests that that the difference in results arises from transforming the functional form of the balance sheet ratio.

Having established that the differences arise from statistical modeling choices, we suggest that our methods and data may be may be preferable. First, the transformation of balance sheet variables in Grossman (2007) seems arbitrary. Source documents and manuals by practitioners from the period show analyses conducted on the levels and differences of the data (Garcia, 1935). We use those variables in our study. We know of no contemporaneous sources that discussed data transformations like those used in Grossman (2007). Second, the transformation $\ln (x /(1-x))$ is neither linear nor monotonic. It dramatically inflates differences between data points with low capital ratios (i.e., high leverage). Third, including the lagged dependent variable on the right-hand side can lead to biased and inconsistent estimates. If there is no serial correlation, the inclusion of a lagged dependent variable will mean that OLS is biased but consistent (Keele and Kelly, 2006). However, if there is serial correlation, then the inclusion of a lagged dependent variable model will mean that OLS is both biased and inconsistent. Coefficients for the lagged dependent variable are usually inflated while coefficients for other explanatory variables are biased toward zero, making it harder to find a statistical relationship between the exogenous variables and the dependent variable. (Achen, 2000; Griliches, 1961; Hibbs, 1974, Maddala and Rao 1973; Malinvaud, 1970, Phillips and Wickens, 1978). Fourth, controlling for state and year fixed effects often yields biased results. 
Calomiris and Wilson (2004) argue that conditional liability could have increased leverage at banks because it protected depositors from losses and allowed banks to attract more deposits for any particular level of capital. This result arises because, in their model, all banks pay the same rate to depositors. Thus, banks compete for deposits based on the safety of their portfolios.

In Table 7, we regress state-bank leverage on the array of explanatory variables that shape the behavior of banks in the Calomiris-Wilson model. We add the cash-to-asset and loan-to-asset ratios as measures of portfolio quality; average bank size as a measure of depositor risk and perhaps also ownership concentration; an indicator variable for years in which the Federal Deposit Insurance Corporation operated; interactions between the indicator variables and average bank size; and the average cost of deposits and cost of capital for national banks in each state. Calomiris and Wilson's model suggests that if we properly control for other balance sheet characteristics and institutional changes, then double liability should lead to more leverage (i.e. a higher asset/equity ratio) rather than less. Column (1) indicates that adding additional balance-sheet ratios (and other banks characteristics) as controls does not alter our result. This result remains robust to alternative regression specifications.

Our results likely differ from those suggested by the Calomiris and Wilson because, for at least a part of our sample period, banks paid depositors different rates of interest and these rates varied geographically (and over time). Sometimes depositors moved funds to high-return, high-risk banks. In other times, depositors' fears outweighed their greed, and they shifted funds towards low-risk banks. Banks that wanted to increase leverage likely did so by paying higher rates on deposits. We test this idea in columns (2) and (3) by adding to the Calomiris-Wilson specification the average cost of deposits and the cost of capital. Both are statistically significant and substantial in magnitude. On average, banks that increased interest to depositors by 1 percent increased their leverage ratio by 0.31 .

Our results nevertheless can be reconciled with the Calomiris-Wilson model and their empirical interpretation of the 1930s "capital crunch." The banking legislation of 1933 and 1935 prohibited banks from paying interest on demand 
deposits. After that point in time, the Federal Reserve member banks in New York City (which are the subset that Calomiris and Wilson examine) did not compete on price for commercial and interbank deposits. In this place and period, banks behaved as predicted by the Calomiris-Wilson model.

\section{Implications and Conclusion}

Some commentators have argued that the repeal of the Glass Steagall Act permitted Wall Street investment banking firms to gamble with their depositors' money that was held in affiliated commercial banks. ${ }^{21}$ These criticisms may, in part, miss the mark as they deflect attention from how the passage of Glass Steagall and the Banking Act of 1935 all but eliminated contingent liability for commercial banks and significantly altered the landscape for risk taking by the financial industry.

Our statistical results indicate that eliminating contingent liability increased risk taking by bankers - a shield that had provided some protection to depositors for three quarters of a century. A system that had led banks to leverage less and close earlier when they were losing money was "replaced" by Congress with deposit insurance, stricter regulation of lending and borrowing practices for banks, and beefed up capital requirements. In place of contingent liability, Congress substituted deposit insurance and strengthened bank capital. It has been well documented that the introduction of federal deposit insurance removed the incentive for most depositors to monitor banks, and introduced moral hazard (Calomiris, 1990; Demirgüç-Kunt and Kane, 2002).

The net result of these changes was to take the monitoring of risk out of banks' hands and place it in the governments' hands. Deposit insurance required the FDIC to ensure that banks' contributions to the deposit insurance fund were weighted according to risk, and to have faith in the FDIC's ability to understand and monitor bank risk taking. Lending and borrowing restrictions meant that examiners had to carefully examine

\footnotetext{
${ }^{21} \wedge \mathrm{http} / / /$ www.dailykos.com/story/2008/03/17/475756/-Banking-Deregulation-and-Clinton

$\wedge$ http://www.investopedia.com/articles/03/071603.asp

$\wedge$ "Sold Out: How Wall Street and Washington Betrayed America, March 2009, Consumer Education

Foundation" www.wallstreetwatch.org

$\wedge$ "Clinton repeal of Glass-Steagall faulty as seen today" March 17th, 2008, http://mortgageblues.us/news/398

$\wedge$ "The Repeal of Glass-Steagall" http://motherjones.com/kevin-drum/2009/03/repeal-glass-steagall

$\wedge$ http://www.alternet.org/news/146900/nouriel_roubini\%3A_how_to_break_up_the_banks,_stop
} 
balance sheets to ensure compliance, but with government agencies serving as the backstops for the banking system, this created incentives for banks to take on additional risks or "game the system" by making their portfolios difficult to monitor.

New Deal banking reforms had other unintended consequences that affected risk taking. For example, even without deposit insurance, the decision by policymakers to marginalize bank liability and elevate the importance of capital and surplus effectively shifted the burden of monitoring banks to regulators. Liability requirements are straightforward, requiring little oversight. Capital requirements, on the other hand, place demands on regulators to verify balance sheet particulars with regularity, and then report these publicly to achieve market discipline. Executing this task, however, is complicated by reporting standards (marking to market versus book value) and the opacity of many types of assets. Banks have become increasingly adept at satisfying regulatory capital by shifting assets "off the balance sheet." Regulators struggle to maintain compliance and ensure banks have "skin in the game," but banks today seem more than capable of amassing risk despite capital regulation.

Other features of New Deal legislation likely reinforced risk taking by financial firms. For example, the Glass-Steagall Act created a firewall between investment banking and commercial banking, and eliminated the ability for commercial banks to carry as brokerages and underwrite securities. ${ }^{22}$ Large financial firms of the period, like J.P. Morgan, were forced to change their business model in order to comply. Federal bank regulators thus came to view the investment banks as outside their regulatory and supervisory domain, and no new agency was created to manage directly the risk taking of investment banks. Partnerships had traditionally provided a mechanism for restraint and self control of investment banks, and external oversight potentially provided a way to reinforce prudent behavior. However, by the 1970s, neither of these conditions existed. Almost all the major American investment banks began to raise funds through stock issuance (abandoning the partnership model) and direct their managers to pursue objectives that responded to outside shareholders. With access to public markets, investment banks could more easily acquire funds and their increase leverage. Glass

\footnotetext{
${ }^{22}$ Gramm-Leach-Bliley Act (GLBA) repealed the two provisions of Glass Steagall restricting affiliations between banks and securities firms in 1999, the same year that the last major investment bank in the U.S. went public.
} 
Steagall thus had the unintended consequence of moving investment banks beyond the purview of bank regulators, shifting oversight to the S.E.C., an agency created in the 1930s to regulate securities markets but given little if any mandate to oversee other types of behavior of investment banks or act as their prudential regulator. 


\section{References}

Banking Law Journal . "Double Liability of State Banks." Vol. 58, Issue 1, pp. 19-23. 58 Banking L. J. 19 (January to December 1941)

Banking Law Journal . "Banking Legislative Trends in the States." Vol. 73, Issue 11 , pp. 871-874, 73 Banking L. J. 871 (1956)

Banking Law Journal . "Banking Legislative Trends in the States." Vol. 73, Issue 10 , pp. 771-777. 73 Banking L. J. 771 (1956)

Barth, James R., Gerard Caprio, Jr., and Ross Levine (2006). Rethinking Bank Regulation till Angels Govern (Cambridge: Cambridge University Press).

Board of Governors of the Federal Reserve System (U.S.), 1959, All Bank Statistics 1896 - 1955, accessed Jul 18, 2012 from FRASER, http://fraser.stlouisfed.org/publication/?pid=39

Calomiris, Charles W. (1990). "Is Deposit Insurance Necessary? A Historical Perspective.” Journal of Economic History 50(2): 283-95.

Calomiris, Charles and Berry Wilson (2004). "Bank Capital and Portfolio Management: The 1930s "Capital Crunch" and the Scramble to Shed Risk." The Journal of Business, Vol. 77, No. 3 (July 2004), pp. 421-455.

Calomiris, Charles W. (2008a). "Banking Crises," NBER Reporter (National Bureau of Economic Research), no. 4: 10-14.

Calomiris, Charles W. (2011). "The Political Lessons of Depression-Era Banking Reform." Oxford Review of Economic Policy.

Chung, Ching-Yi and Gary Richardson. (2007). Ching-Yi Chung and Gary Richardson. "Deposit Insurance Altered the Composition of Bank Suspensions during the 1920s: Evidence from the Archives of the Board of Governors" The B.E. Journal of Economic Analysis \& Policy 5.1 (2007).

Demirguc-Kunt, Asli, Edward Kane, and Luc Laeven, eds (2009). Deposit Insurance Around the World (Cambridge, Mass.: MIT Press).

Demirgüç-Kunt, Asli and Edward J. Kane. (2002). "Deposit Insurance Around the Globe: Where Does It Work?” Journal of Economic Perspectives 16:175-176.

Drucker, Steven and Puri, Manju. (2006). "Banks in Capital Markets: A Survey." In Handbook in Corporate Finance: Empirical Corporate Finance, edited by B. Espen Eckbo Elsevier/North-Holland: New York. 
Esty, Benjamin C. (1998). "The Impact of Contingent Liability on Commercial Bank Risk Taking.” Journal of Financial Economics 47:189-218.

Flood, Mark D. United States Historical Data on Bank Market Microstructure, 18961955[Computer file]. ICPSR version. [producer] Mark Flood. Montreal, Quebec:

Concordia University, 1998. [distributor], Ann Arbor, MI: Inter-university Consortium

for Political and Social Research 1998. doi:10.3886/ICPSR02393.v1

Friedman, Milton and Anna J. Schwartz. (1963). A Monetary History of the United States

Garcia, Ferdinand Lawrence. (1947). How to analyze a bank statement. Bank Study

series. Boston: Bankers Publishing Company.

Garlock, Fred. L. (1926). "Bank Failures in Iowa." Journal of Land \& Public Utility

Economics 2(1): 48-66

Grossman, Richard S. (2001). "Double Liability and Risk Taking.” Journal of Money, Credit and Banking 33(2): 143-159

Grossman, Richard S. (2007). Fear and Greed: The Evolution of Double Liability in American Banking, 1865-1930.” Explorations in Economic History 44: 59-80

Jackson, Howell E. (1993). "Losses from National Bank Failures during the Great Depression: A Response to Professors Macey and Miller." Wake Forest Law Review 28 (Winter): 919-32.

Kane, Edward J. and Berry K. Wilson. (1996). "The Demise of Double Liability as an Optimal Contract for Large-Bank Stockholders.” NBER Working Paper 5848 (December).

Kroszner, Randall S. (1998). "Rethinking Bank Regulation: A Review of the Historical Evidence." Journal of Applied Corporate Finance (summer): 48-58.

Kroszner, Randall S. and Raguram Rajan. (1994). "Is the Glass-Steagall Act Justified? A Study of the U.S. Experience with Universal Banking before 1933." American Economic Review 84(4): 810-832.

Kuttner, Robert. (2007). “The Alarming Parallels Between 1929 and 2007," The American Prospect: October 2, p.2.

Lamoreaux, Naomi R. (1986). "Banks, Kinship, and Economic Development: The New England Case." Journal of Economic History vol. 46, 647-667.

Lamoreaux, Naomi R. (1994). Insider Lending: Banks, Personal Connections, and Economic Development in Industrial New England. Cambridge: Cambridge University Press. 
Macey, Jonathan R. and Geoffrey P. Miller. (1992). "Double Liability of Bank Shareholders: History and Implications." Wake Forest Law Review 27: 31-62.

Macey, Jonathan R. and Geoffrey P. Miller. (1992). "Double Liability of Bank Shareholders: A Look at the New Data." Wake Forest Law Review 28: 933-41.

Joseph Manfrini (1959). Branch Bank Stocks Cited as 'Better'. The Analysts Journal 15(1): 77-79

Marquis, Ralph W. and Frank P. Smith. "Double Liability for Bank Stock." "Federal Legislation Affecting Banks." Banking Law Journal, Vol. 51, Issue 4 , pp. 349-360. 51 Banking L. J. 349 (January to December 1934)

Mitchener, Kris James. (2007). "Are Supervision and Regulation Pillars of Financial Stability? Evidence from the Great Depression," Journal of Law and Economics vol. 50 (May), 273-302.

Mitchener, Kris James. (2005). "Bank Supervision, Regulation, and Financial Instability during the Great Depression.” Journal of Economic History vol. 65 (March), 152-85

Morrison, Alan D. and William J. Wilhelm. (2008). "The Demise of Investment-Banking Partnerships: Theory and Evidence." Journal of Finance 63(1): 311-350.

Oesterle, Dale A. (1992). "Limited Liability, Development of," in the Palgrave Dictionary of Money and Finance, vol. 2. London: Macmillan, pp.590-1.

Paton, Thomas Bugard, and Thomas B. Paton. 1926. Paton's Digest: a digest of legal opinions of Thomas B. Paton, general counsel of the American Bankers Association. American Bankers Association.

Paton, T. B., \& American Bankers Association. (1946). Paton's digest of legal opinions. Supplement. New York.

Perlo, Victor. (1958). "People's Capitalism" and Stock-Ownership. American Economic Review, Vol. 48, No. 3 (Jun., 1958), pp. 333-347

Puri, Manju. (1996). "Commercial banks in investment banking conflict of interest or certification role?” Journal of Financial Economics 40: 373-401.

Stiglitz, Joseph E. (2009). “Capitalist Fools,” Vanity Fair, January, p. 2.

U.S. Congress, (1963a). Committee on Banking and Currency, House of Representatives. Bank Holding Companies, Scope of Operations and Stock Ownership, 88th Congress, May 20, 1963 (Washington, D.C.: U.S. Government Printing Office).

U.S. Congress. (1963b). Report to the Select Committee on Small Business, House of Representatives. Chain Banking: Stockholder and Loan Links of 200 Largest Member 
Banks, 87th Congress, January 3, 1963 (Washington, D.C.: U.S. Government Printing Office).

U.S. Congress. (1966) Subcommittee on Domestic Finance, Committee on Banking and Currency, U.S. House of Representatives, Bank Stock Ownership and Control, 89th Congress, December 29, 1966 (Washington D.C.: U.S. Government Printing Office).

Vernon, Jack R. (1970) “Ownership and Control Among Large Member Banks.” The Journal of Finance 25(3): 651-657.

Vincens, John R. (1957). "On the Demise of Double Liability of Bank Shareholders." Business Law Journal (April) pp. 275-9

Vincens, John R. "On the Demise of Double Liability of Bank Shareholders.” Banking Law Journal , Vol. 75, Issue 3 , pp. 213-218. 75 Banking L. J. 213 (January to December 1958)

White, Eugene. (2013). “To Establish a More Effective Supervision of Banking: How the Birth of the Fed Altered Bank Supervision," in William Robards, (ed.) A Return to Jekyll Island: The Origins, History and Future of the Federal Reserve Cambridge: Cambridge University Press.

White, Eugene. (2010). "Banking and Finance in the Twentieth Century," in Stanley L. Engerman and Robert E. Gallman (eds.) The Cambridge Economic History of the United States, vol. III. Cambridge: Cambridge University Press.

Willis, H. Parker. (1935). "The Banking Act of 1933 in Operation," Columbia Law Review 35(5): 697-724. 
Table 1: Changes in Bank Liability Laws, 1910 through 1940

\begin{tabular}{|c|c|c|c|c|c|c|}
\hline & \multirow{3}{*}{ Jurisdiction } & \multirow{3}{*}{$\begin{array}{l}\text { Status } \\
1910\end{array}$} & \multicolumn{3}{|c|}{ Changes After 1910} & \multirow{3}{*}{ Requirements for Termination of Double Liability } \\
\hline & & & \multirow{2}{*}{ Begin } & \multicolumn{2}{|c|}{$\begin{array}{l}\text { Eliminate Liability } \\
\text { for .... Stock }\end{array}$} & \\
\hline & & & & New & Existing & \\
\hline & National & Double & & 1933 & 1937 & $\begin{array}{l}\text { Six month notice, and retain earnings until surplus } \\
\text { equals capital. }\end{array}$ \\
\hline 1 & Arizona & Limited & 1912 & 1956 & 1956 & Join FDIC. \\
\hline 2 & Arkansas & Limited & 1912 & 1933 & 1935 & Join FDIC. \\
\hline 3 & California & Unlimited & & 1937 & 1937 & Join FDIC and six month notice. \\
\hline 4 & Colorado & Triple & & 1939 & 1939 & Join FDIC. \\
\hline 5 & Florida & Double & & 1937 & 1937 & Join FDIC; surplus must equal capital. \\
\hline 6 & Georgia & Double & & 1937 & 1937 & $\begin{array}{l}\text { Stockholders remain liable for unpaid stock. No } \\
\text { new protections. }\end{array}$ \\
\hline 7 & Idaho & Double & & 1923 & 1923 & \\
\hline 8 & Illinois & Double & & 1952 & 1953 & \\
\hline 9 & Indiana & Double & & 1940 & 1941 & $\begin{array}{l}\text { Five month notice for shares issued before } \\
\text { December } 1940 \text {. }\end{array}$ \\
\hline 10 & Iowa & Double & & 1933 & 1938 & \\
\hline 11 & Kansas & Double & & 1937 & 1937 & $\begin{array}{l}\text { Six month notice for shares issued before } 23 \\
\text { March } 1937 \text {. }\end{array}$ \\
\hline 12 & Kentucky & Double & & 1937 & 1937 & $\begin{array}{l}\text { Six month notice. Accumulate additional surplus } \\
\text { (a). }\end{array}$ \\
\hline 13 & Maine & Double & & 1933 & 1933 & $\begin{array}{l}\text { Bank stock issued before } 16 \text { December } 1933 \\
\text { exempt if surplus equals capital, else stockholders } \\
\text { liable for amount capital exceeds surplus. }\end{array}$ \\
\hline 14 & Maryland & Double & & 1937 & 1937 & $\begin{array}{l}\text { Three month notice; exempt banks must annually } \\
\text { transfer } 10 \% \text { of earnings to surplus until surplus } \\
\text { equals capital. }\end{array}$ \\
\hline 15 & Massachusetts & Double & & 1934 & 1934 & $\begin{array}{l}\text { Six month notice for stock issued before } 1 \text { June } \\
\text { 1934. Accumulate additional surplus (a). }\end{array}$ \\
\hline 16 & Michigan & Double & & 1937 & 1937 & $\begin{array}{l}30 \text { days' notice. Accumulate additional surplus } \\
\text { (a). }\end{array}$ \\
\hline 17 & Minnesota & Double & & & & Join FDIC. \\
\hline 18 & Mississippi & Limited & 1914 & 1934 & 1934 & $\begin{array}{l}\text { Join FDIC and six month notice for stock issued } \\
\text { before } 24 \text { Oct } 1933\end{array}$ \\
\hline 19 & Montana & Double & & 1936 & 1936 & Join FDIC. \\
\hline 20 & Nebraska & Double & & 1938 & 1938 & \\
\hline
\end{tabular}




\begin{tabular}{|c|c|c|c|c|c|c|}
\hline & \multirow{3}{*}{ Jurisdiction } & \multirow{3}{*}{$\begin{array}{c}\text { Status } \\
1910\end{array}$} & \multicolumn{3}{|c|}{ Changes After 1910} & \multirow{3}{*}{ Requirements for Termination of Double Liability } \\
\hline & & & \multirow{2}{*}{ Begin } & \multicolumn{2}{|c|}{$\begin{array}{l}\text { Eliminate Liability } \\
\text { for .... Stock }\end{array}$} & \\
\hline & & & & New & Existing & \\
\hline 21 & Nevada & Limited & 1911 & 1933 & 1933 & \\
\hline 22 & New Hampshire & Limited & 1911 & 1937 & 1937 & $\begin{array}{l}\text { Six month notice on stock issued before } 1 \text { Jan } \\
1911 \text { or after } 1 \text { Jun } 1937 \text {. }\end{array}$ \\
\hline 23 & New Mexico & Double & & 1935 & 1935 & \\
\hline 24 & New York & Double & & 1937 & 1937 & $\begin{array}{l}\text { Six month notice. Minimum surplus raised to } 65 \% \\
\text { from } 20 \% \text { of capital. }\end{array}$ \\
\hline 25 & North Carolina & Double & & 1935 & 1935 & $\begin{array}{l}\text { Surplus equal to } 50 \% \text { of capital must be invested } \\
\text { in state or US government bonds; if deficiency, } \\
\text { stockholders liable. }\end{array}$ \\
\hline 26 & North Dakota & Double & & 1939 & 1939 & Six month notice. \\
\hline 27 & Ohio & Double & & 1937 & 1937 & $\begin{array}{l}\text { Stockholders liable for unpaid stock. No new } \\
\text { protections. }\end{array}$ \\
\hline 28 & Oklahoma & Double & & 1937 & 1937 & $\begin{array}{l}\text { Join FDIC, three month notice. Stock issued after } \\
28 \text { April } 1937 \text { exempt. }\end{array}$ \\
\hline 29 & Oregon & Limited & 1912 & & & \\
\hline 30 & Pennsylvania & Double & & 1939 & 1939 & $\begin{array}{l}\text { Limited liability on shares issued after } 1 \mathrm{Sept} \\
\text { 1939. Other shares double liable if surplus below } \\
\text { capital. After } 1 \text { July } 1941 \text {, double liability ceases } \\
\text { on six-month notice. }\end{array}$ \\
\hline 31 & South Carolina & Double & & 1935 & 1935 & $\begin{array}{l}\text { Except for banks judged insolvent before } 21 \\
\text { September 1935. Accumulate additional surplus } \\
\text { (a). }\end{array}$ \\
\hline 32 & South Dakota & Double & & 1936 & 1936 & $\begin{array}{l}\text { Join FDIC. For non-members, double liability } \\
\text { continues for } 1 \text { year after transfer of shares. }\end{array}$ \\
\hline 33 & Texas & Double & & 1937 & 1937 & \\
\hline 34 & Utah & Double & & 1940 & 1940 & \\
\hline 35 & Vermont & Double & & 1933 & & $\begin{array}{l}\text { Shares issued prior to } 24 \text { March } 1933 \text { remain } \\
\text { doubly liable. }\end{array}$ \\
\hline 36 & Washington & Double & & 1940 & 1940 & $\begin{array}{l}\text { Join FDIC or furnish security of payment } \\
\text { equivalent to that required by national banks. }\end{array}$ \\
\hline 37 & West Virginia & Double & & 1938 & 1938 & $\begin{array}{l}\text { Join FDIC or surplus equal } 50 \% \text { capital, and three } \\
\text { months' notice. }\end{array}$ \\
\hline 38 & Wisconsin & Double & & 1937 & 1937 & Join FDIC. Six month notice. \\
\hline 39 & Wyoming & Double & & 1937 & 1937 & Join FDIC. 60 days' notice. \\
\hline
\end{tabular}

Notes: (a) Source appears to indicate 'accumulate surplus equal to capital' but exact amount of required accumulation unclear.

Sources: See text. 
Table 2: Leverage and Stockholder Liability with and without Double Liability Dependent Variable: Average state bank asset-equity ratio

\begin{tabular}{lcc}
\hline Independent Variable & & \\
\hline & & \\
Double Liability & $(0.150)$ & $(0.132)$ \\
& & \\
National Bank Assets to Equity Ratio & & $0.709^{* * * *}$ \\
& & $(0.030)$ \\
Constant & $4.086^{* * *}$ & $1.583^{* * *}$ \\
& $(0.371)$ & $(0.295)$ \\
Observations & 2208 & 2208 \\
R-squared & 0.81 & 0.88 \\
& & \\
\hline
\end{tabular}

Notes: *** indicate significant at $1 \%$. All specifications estimated with state and year fixed effects. HuberWhite robust standard errors are shown in parentheses. Dependent variable is the sum of assets in all statechartered banks in each state in each year divided by the sum of equity, defined as paid-up capital (common and preferred stock), surplus, undivided profits, unpaid dividends, and all other retained earnings. Independent variable is the equivalent value for the nationally-chartered banks within each state. 
Table 3: Contingent Liability and Loan Losses before Impairment or Insolvency

\begin{tabular}{lrr}
\hline & \multicolumn{2}{c}{ Dependent Variable } \\
\cline { 2 - 3 } Independent Variable & $0.682^{* *}$ & $1.667^{* * *}$ \\
\cline { 2 - 3 } Double Liability & $(0.310)$ & $(0.450)$ \\
& & \\
& $0.519^{* * *}$ & $0.538^{* * *}$ \\
National Bank Ratio & $(0.038)$ & $(0.030)$ \\
& & \\
Constant & $4.948^{* * *}$ & $14.187^{* * *}$ \\
& $(0.900)$ & $(1.625)$ \\
& & \\
Year Fixed Effects & & Yes \\
State Fixed Effects & Yes & Yes \\
Observations & 2208 & 2208 \\
R-squared & 0.84 & 0.78 \\
& & \\
\hline
\end{tabular}

Notes: $* *$ indicates significance at $5 \%$ level. $* * *$ indicates significant at $1 \%$ level. Huber-White standard errors are shown in parentheses. All specifications estimated with state and year fixed effects. Observations exist for each state for each year from 1910 through 1955. In column (1), the dependent variable is the sum of retained earnings in all state-chartered banks in each state in each year divided by the sum of total loans at all state-chartered banks in each year. In column (2), the dependent variable is the sum of capital and retained earnings divided by the sum of loans. In each column, the independent variable is the equivalent ratio for the nationally-chartered banks within each state. 
Table 4: Leverage and Requirements for Opting Out of Double Liability

$\underline{\text { Independent Variable }}$

Double Liability

$\underline{\text { Requirements for Opting Out of Double Liability }}$

Join FDIC

Notice

Increase Surplus

National Bank Retained Earnings to Loans

Constant

Year Fixed Effects

State Fixed Effects

Robust Standard Errors

Observations

R-squared
Dependent Variable: Assets / Capital

$\begin{array}{rrr}-2.999 & -0.594 & -0.317 \\ (0.306)^{* * *} & (0.287)^{* *} & (0.224)\end{array}$


Table 5. Regression Specifications Using Alternative Functional Form and Lagged Dependent Variables Dependent Variable and Functional Form

\begin{tabular}{|c|c|c|c|c|c|c|}
\hline \multirow[b]{2}{*}{$\begin{array}{l}\text { Independent } \\
\text { Variable }\end{array}$} & \multicolumn{3}{|c|}{ Cash to Deposit Ratio } & \multicolumn{3}{|c|}{ Asset to Equity Ratio } \\
\hline & $\ln (\mathrm{x} /(1-\mathrm{x}))$ & $\mathrm{X}$ & $\ln (\mathrm{x} /(1-\mathrm{x}))$ & $\ln (\mathrm{x} /(1-\mathrm{x}))$ & $\mathrm{x}$ & $\ln (\mathrm{x} /(1-\mathrm{x}))$ \\
\hline $\begin{array}{l}\text { Double } \\
\text { Liability }\end{array}$ & $\begin{array}{r}0.025 \\
(0.007)^{* *}\end{array}$ & $\begin{array}{r}0.003 \\
(0.001)^{*}\end{array}$ & $\begin{array}{r}-0.152 \\
(0.027)^{* *}\end{array}$ & $\begin{array}{r}0.014 \\
(0.005)^{* *}\end{array}$ & $\begin{array}{r}-0.280 \\
(0.047)^{* *}\end{array}$ & $\begin{array}{r}0.390 \\
(0.018)^{* *}\end{array}$ \\
\hline $\begin{array}{l}\text { Lagged } \\
\text { Dependent } \\
\text { Variable }\end{array}$ & $\begin{array}{r}0.882 \\
(0.007)^{* *}\end{array}$ & $\begin{array}{r}0.943 \\
(0.007)^{* *}\end{array}$ & & $\begin{array}{r}0.854 \\
(0.007)^{* *}\end{array}$ & $\begin{array}{r}0.954 \\
(0.006)^{* *}\end{array}$ & \\
\hline $\begin{array}{l}\text { National Bank } \\
\text { Analog of DV }\end{array}$ & $\begin{array}{r}0.214 \\
(0.012)^{* *}\end{array}$ & & & $\begin{array}{r}0.123 \\
(0.007)^{* *}\end{array}$ & & \\
\hline Constant & $\begin{array}{r}0.040 \\
(0.010)^{* *}\end{array}$ & $\begin{array}{r}0.010 \\
(0.002)^{* *}\end{array}$ & $\begin{array}{r}-1.263 \\
(0.020)^{* *}\end{array}$ & $\begin{array}{r}-0.062 \\
(0.012)^{* *}\end{array}$ & $\begin{array}{r}0.741 \\
(0.072)^{* *}\end{array}$ & $\begin{array}{r}-2.231 \\
(0.013)^{* *}\end{array}$ \\
\hline $\begin{array}{l}\text { Observations } \\
\text { R-squared }\end{array}$ & $\begin{array}{r}2160 \\
0.94\end{array}$ & $\begin{array}{r}2160 \\
0.90\end{array}$ & $\begin{array}{r}2208 \\
0.01\end{array}$ & $\begin{array}{r}2160 \\
0.96\end{array}$ & $\begin{array}{r}2160 \\
0.94\end{array}$ & $\begin{array}{r}2208 \\
0.17\end{array}$ \\
\hline
\end{tabular}

Notes: Standard errors in parentheses. Asterisk * indicates significant at 5\%; ** significant at $1 \%$. 
Table 6: Alternative Specifications Incorporating the Calomiris-Wilson Model

\begin{tabular}{|c|c|c|c|}
\hline \multirow[b]{2}{*}{ Independent Variable } & \multicolumn{3}{|c|}{$\begin{array}{c}\text { Dependent Variable } \\
\text { State Bank Leverage Ratio }\end{array}$} \\
\hline & $(1)$ & $(2)$ & (3) \\
\hline \multirow[t]{2}{*}{ Double Liability (DL) } & -0.625 & -1.850 & -1.737 \\
\hline & $(0.158)^{* *}$ & $(0.322)^{* *}$ & $(0.319)^{* *}$ \\
\hline \multirow[t]{2}{*}{$\mathrm{DL} * \mathrm{FDIC}$} & 0.344 & -0.066 & 0.020 \\
\hline & $(0.205)$ & $(0.458)$ & $(0.452)$ \\
\hline \multirow[t]{2}{*}{ Federal Deposit Insurance Corp. (FDIC) } & -0.063 & -1.050 & -0.987 \\
\hline & $(0.442)$ & $(0.442)^{*}$ & $(0.436)^{*}$ \\
\hline \multirow[t]{2}{*}{ National Bank (NB) Average Size } & 0.262 & -45.835 & -45.432 \\
\hline & $(0.371)$ & $(7.752)^{* *}$ & $(7.651)^{* *}$ \\
\hline \multirow[t]{2}{*}{ National Bank Leverage } & 0.687 & 0.427 & 0.412 \\
\hline & $(0.033)^{* *}$ & $(0.032)^{* *}$ & $(0.032)^{* *}$ \\
\hline \multirow{2}{*}{ National Bank Cash/Asset Ratio } & -1.853 & 8.298 & 8.663 \\
\hline & $(1.229)$ & $(1.287)^{* *}$ & $(1.272)^{* *}$ \\
\hline \multirow[t]{2}{*}{ National Bank Loan/Asset Ratio } & -2.755 & 0.680 & 0.201 \\
\hline & $(0.897)^{* *}$ & $(0.725)$ & $(0.722)$ \\
\hline \multirow[t]{2}{*}{ DL * NB Average Size } & & 41.699 & 40.379 \\
\hline & & $(7.632)^{* *}$ & $(7.537)^{* *}$ \\
\hline \multirow[t]{2}{*}{ FDIC * NB Average Size } & & 11.468 & 12.279 \\
\hline & & (8.997) & $(8.881)$ \\
\hline \multirow[t]{2}{*}{ DL $*$ FDIC $* *$ NB Average Size } & & -8.453 & -8.580 \\
\hline & & (9.772) & $(9.643)$ \\
\hline \multirow[t]{2}{*}{ NB Cost of Deposits } & & 27.845 & 31.644 \\
\hline & & $(11.689)^{*}$ & $(11.563)^{* *}$ \\
\hline \multirow[t]{2}{*}{ NB Cost of Capital } & & & 7.407 \\
\hline & & & $(1.574)^{* *}$ \\
\hline Observations & 2208 & 2208 & 2208 \\
\hline R-squared & 0.88 & 0.85 & 0.85 \\
\hline
\end{tabular}

Notes: Standard errors in parentheses. Asterisk * indicates significant at 5\%; ** significant at 1\%. 
Figure 1: Number of Banks and Double Liability

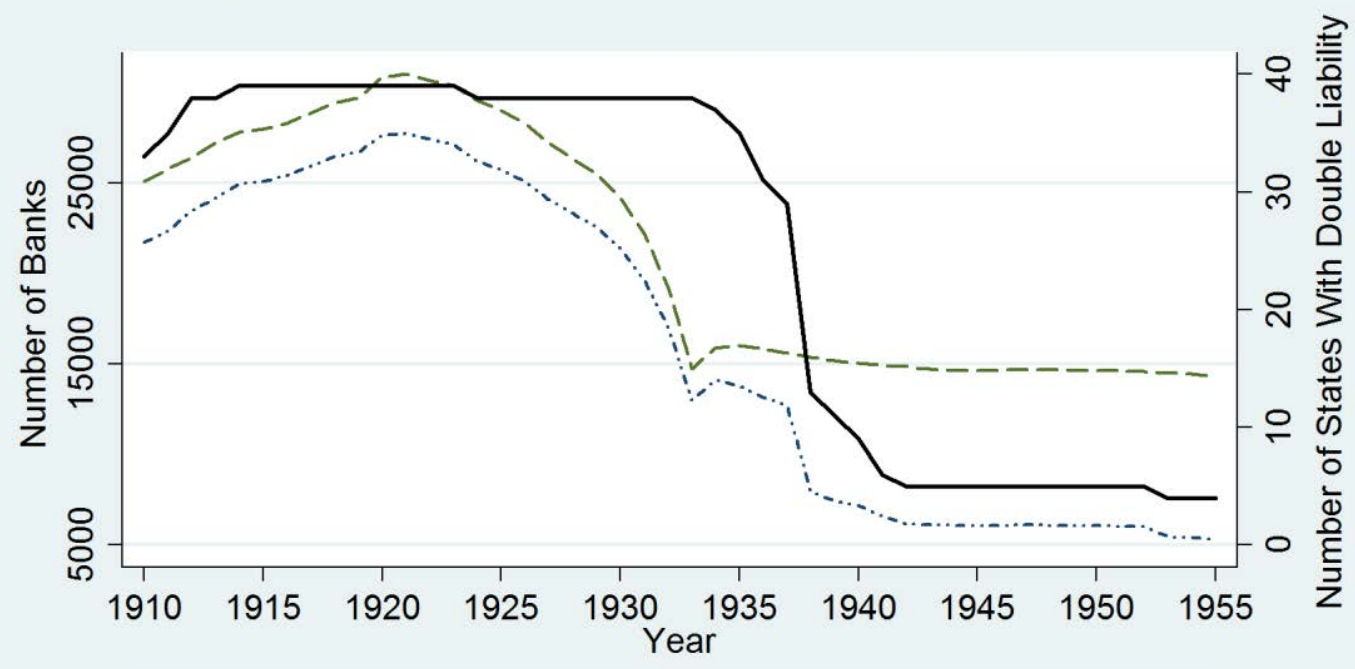

-......... Total \# Banks With Double Liability - - - - . Total \# Banks Total \# States With Double Liability

Note: Number of banks with double liability includes states with triple and unlimited liability. Source: All Bank Statistics and Table 1

\section{Figure 2: Leverage(Assets/Equity)}

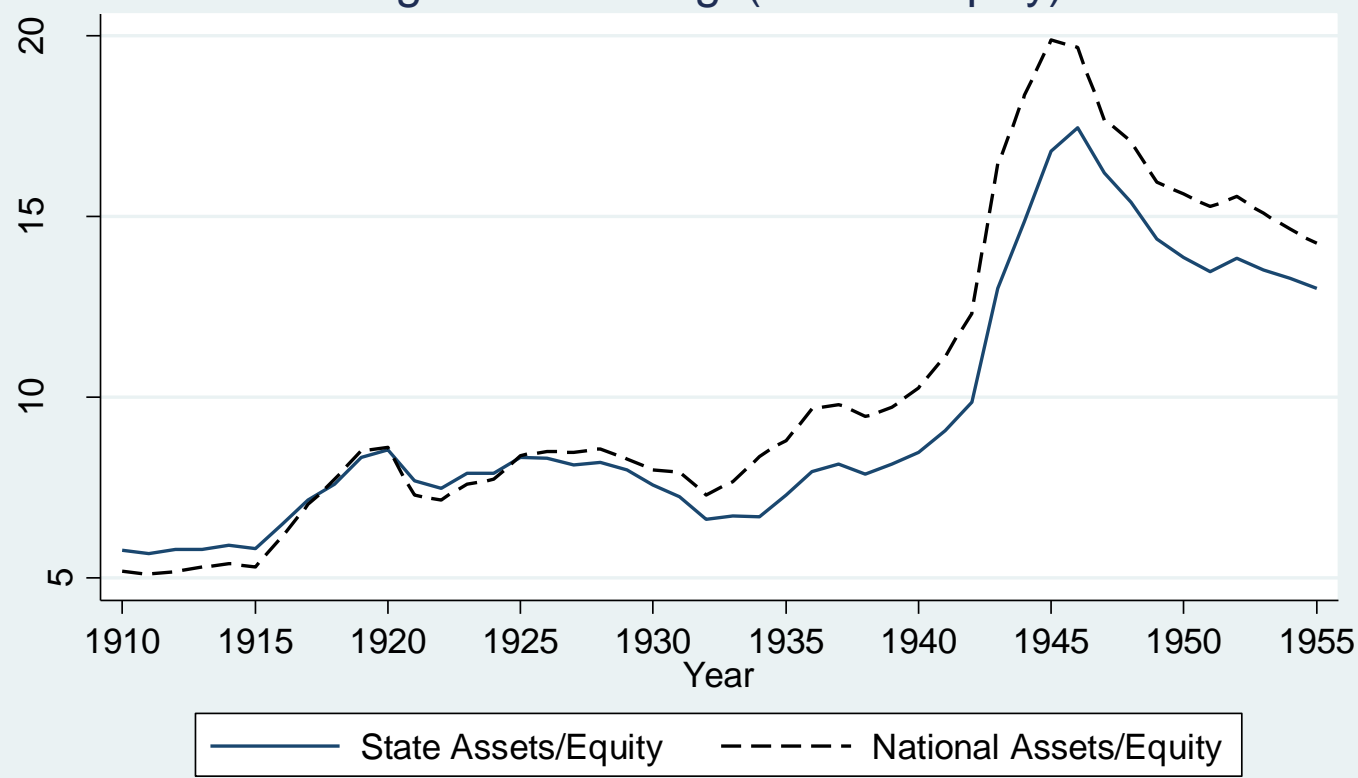

Notes: Aggregate ratio for each state averaged over states. State A/E is ratio for state banks. National is ratio for national banks.

Source: All Bank Statistics 
Figure 3: Loan Losses That Would Exhaust Capital Equity/Loan Ratio for State and National Banks

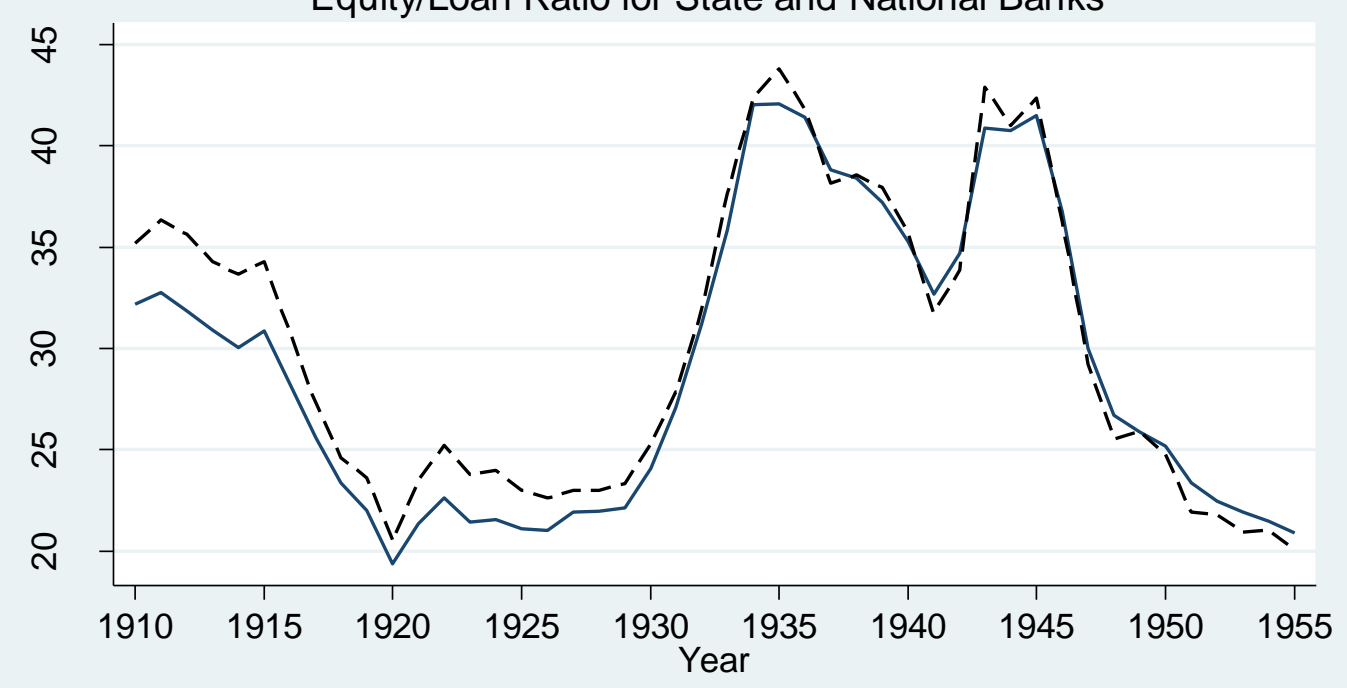

State Bank Equity/Loan - - - - National Bank Equity/Loan

Aggregate ratio for each state averaged over states.

Source: All Bank Statistics

Figure 4: Loan Losses That Would Impair Capital

Retained Earnings/Loan Ratio for State and National Banks

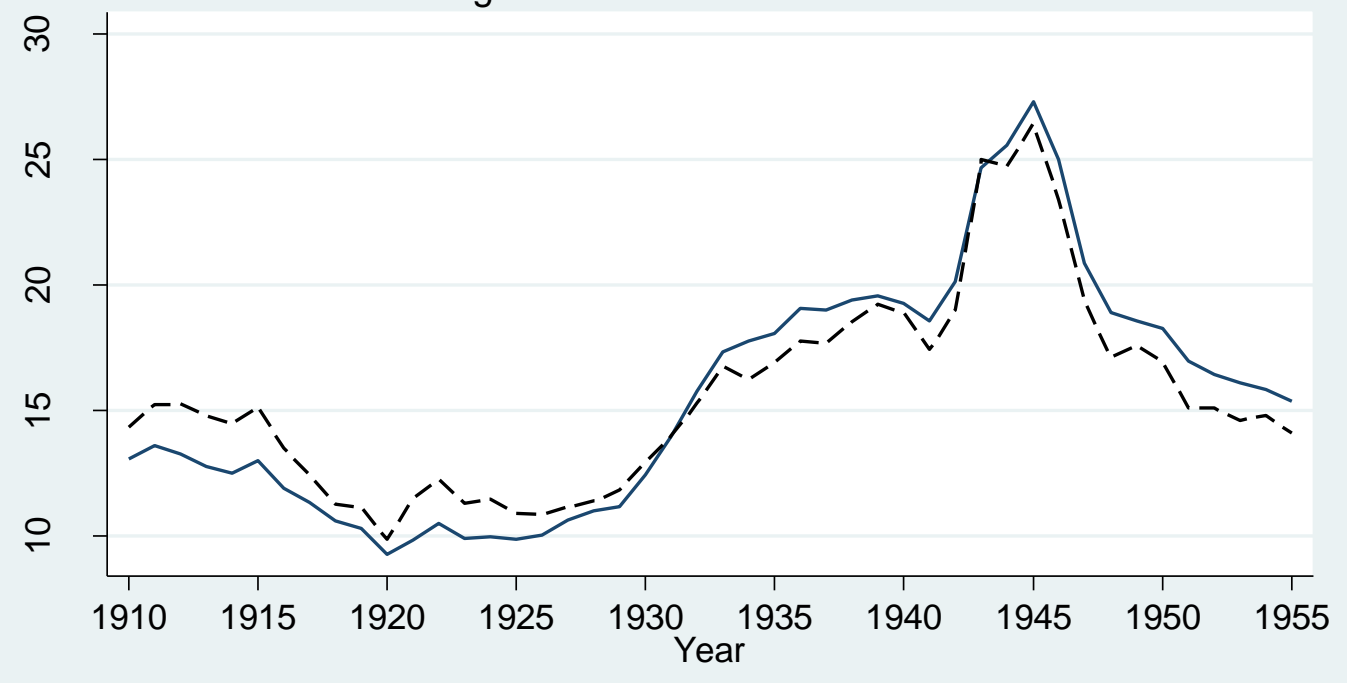

- State Bank Surplus/Loan - - - - National Bank Surplus/Loan

Aggregate ratio for each state averaged over states Source: All Bank Statistics 


\section{Figure 5: Cash Over Asset Ratio}

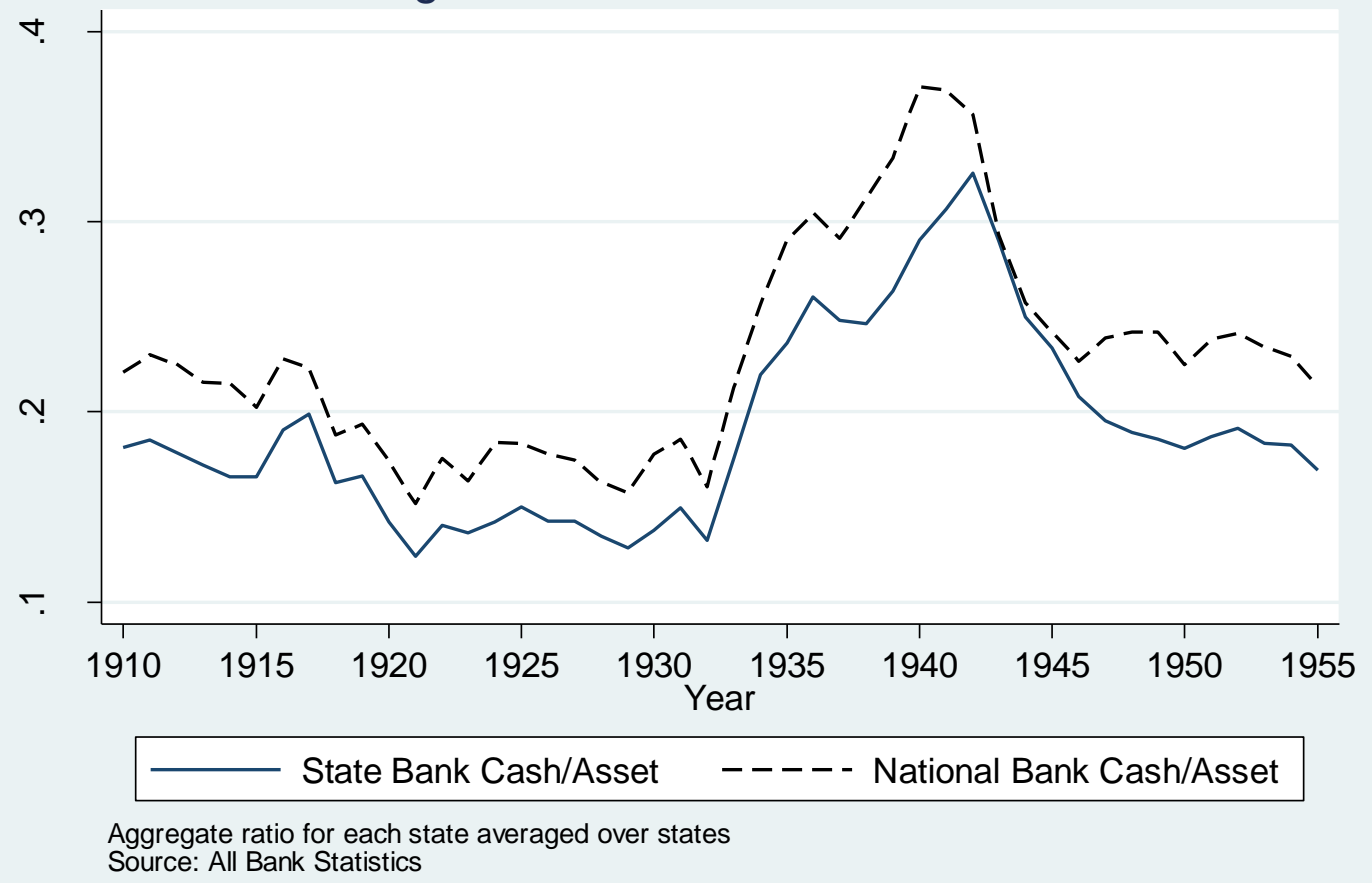

Figure 6: Loan Over Asset Ratio

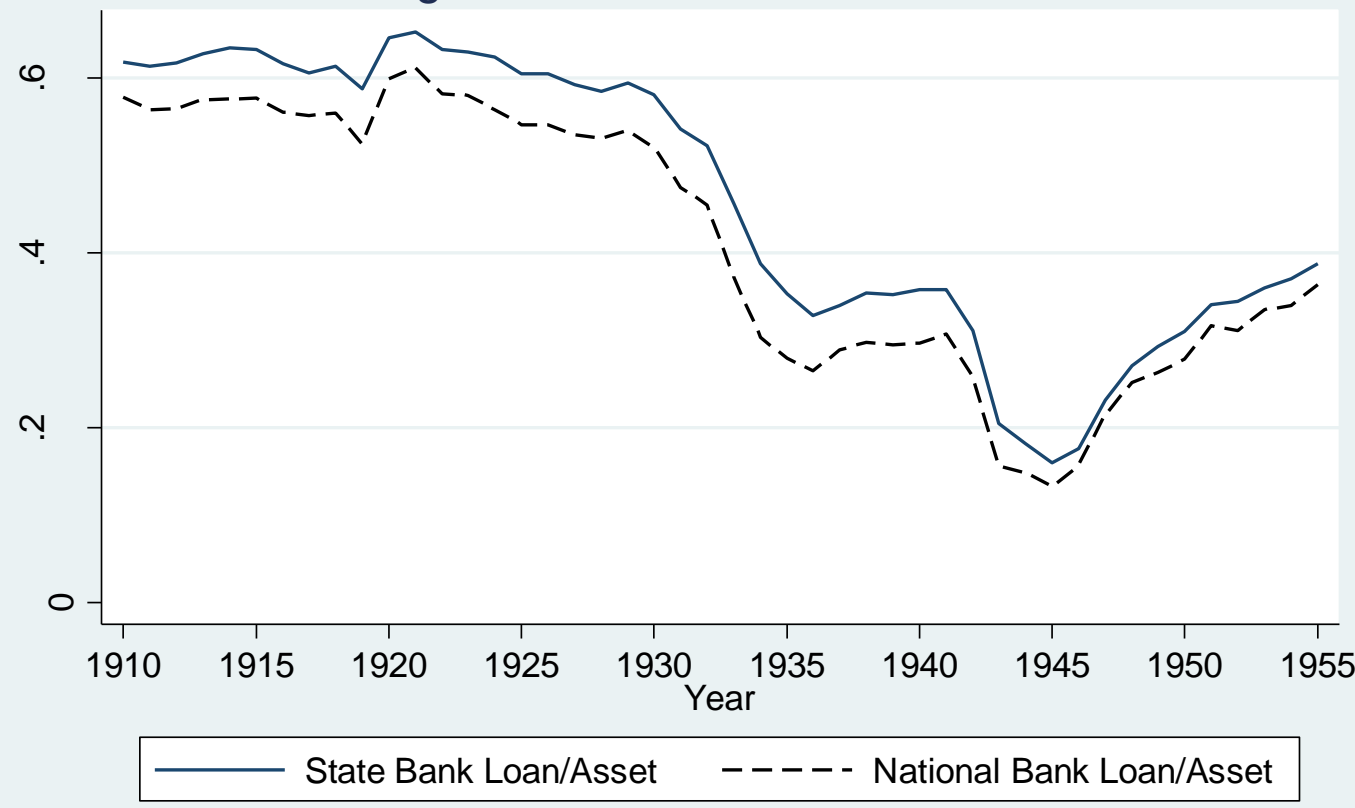

Aggregate ratio for each state averaged over states Source: All Bank Statistics 
Figure 7: Requirements for Opting Out of Double Liability Assets of Banks Operating Under Each Rule

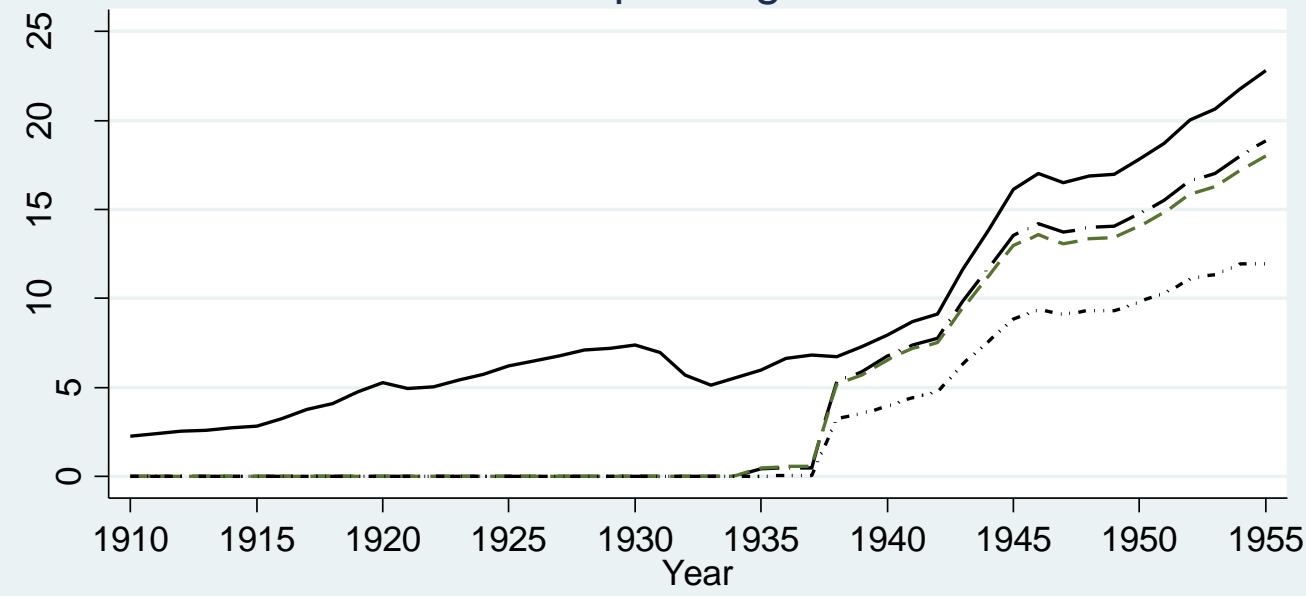

Total US - - - Notice

Surplus - -........ FDIC

Note: Values are the sum of assets of all banks, both national and state, operating under each rule. Total is total asset of all banks in US.

Source: Asset data from All Bank Statistics. Legal data see text.

Figure 8: Requirements for Opting Out of Double Liability Join FDIC or Increase Surplus

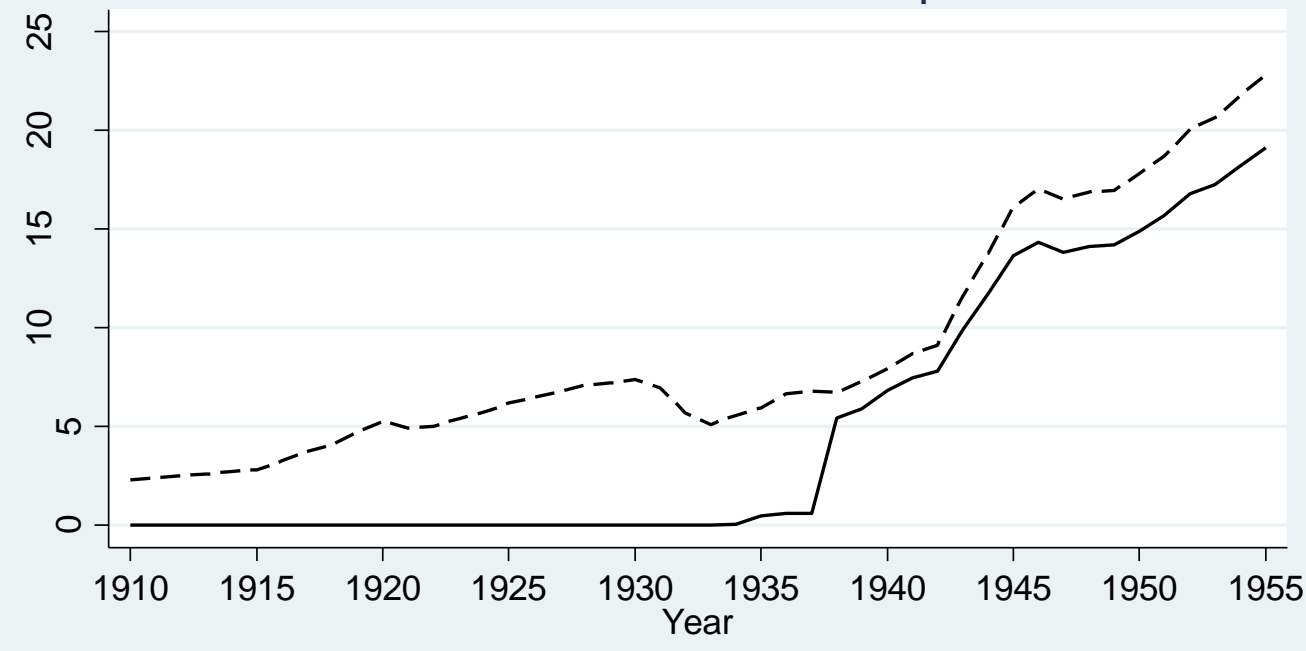

- - - - Total Assets All US Banks — FDIC or Surplus

Values are the sum of assets of all banks, both national and state, operating under the rule.

Total is total asset of all banks in US.

Source: Asset data from All Bank Statistics. Legal data see text. 